\title{
INFLUENCE OF EL NIÑOILA NIÑA EPISODES ON THE RAINFALL REGIME OF THE DL 1 REGION OF THE NORTH CENTRAL PROVINCE OF SRI LANKA
}

\author{
B.V.R. PUNYAWARDENA ${ }^{* 1}$, R. P. DE SILVA ${ }^{2}$ and S. NIJANANTHY ${ }^{2}$ \\ 1 Natural Resources Management Center, Department of Agriculture, Peradeniya. \\ 2 Department of Agricultural Engineering, Faculty of Agriculture, University of Peradeniya, \\ Peradeniya.
}

(Received: 17 June 2003 ; accepted: 1 March 2004)

\begin{abstract}
In view of the significance in terms of agricultural production and its dependency on rainfall, the $\mathrm{DL}_{1}$ region of the North Central Province (NCP) was chosen to study the influence of $E l$ Niño/La Niña episodes on the rainfall regime. The rainfall data of two representative stations as mean seasonal rainfall and mean number of rainy days were analyzed based on four seasons i.e. First Inter-Monsoon (FIM), South West Monsoon (SWM), Second Inter-Monsoon (SIM) and North East Monsoon (NEM). Seasonal time series of rainfall data from 1906 to 2000 were divided into El Niño, La Niña and Neutral years. Student t-test and chi-square test were carried out to determine whether there were significant differences among the mean seasonal rainfall and mean number of rainy days in the time series. Both rainfall amounts and the number of rainy days in SIM seasons showed a statistically significant increase with respect to the situation in Neutral years. Even though it is not statistically significant, an apparent increase of mean seasonal rainfall and the mean number of rainy days in NEM seasons have also been evident during El Niño years. Thus, El Niño years are likely to produce above normal or at least near normal rains during the Maha season in the NCP. Hence, appearance and progression of $E l$ Niño type circulation in the Pacific ocean could be safely used as a long-range forecasting tool for rainfall of the Maha season in the NCP. Although there were obvious differences of seasonal time series of FIM, SIM and NEM between La Niña and Neutral years, statistically significant relationships could not be established. However, the teleconnection between seasonal rainfall during SWM period and La Niña events was positive at both locations. This study reveals that there is an influence of $E l$ Niño and La Niña episodes on the seasonal rainfall regime of $\mathrm{DL}_{1}$ region of the NCP.
\end{abstract}

Key words: El Niño/La Niña episodes, North Central Province, rainfall.

\section{INTRODUCTION}

The $\mathrm{DL}_{1}$ agro-ecological region occupies a large extent of the North Central Province (NCP) of Sri Lanka (Figure 1). It is dominated by a reservoir based irrigation system with a large number of major irrigation tanks along with a cascade of minor tanks. Except for a few major irrigation tanks, which are fed by trans-basin diversion of the Mahaweli river, all other major irrigation and minor tanks are fully dependent on the seasonal rainfall of their respective catchments. In addition, rainfed upland

\footnotetext{
* Corresponding author
} 
cultivation, which provides the livelihood of a majority of peasants in the province, is also heavily dependent on the rainfall during major cultivation seasons. Thus, the amount and the distribution of seasonal rainfall of the NCP determines the agricultural production potential of the region.
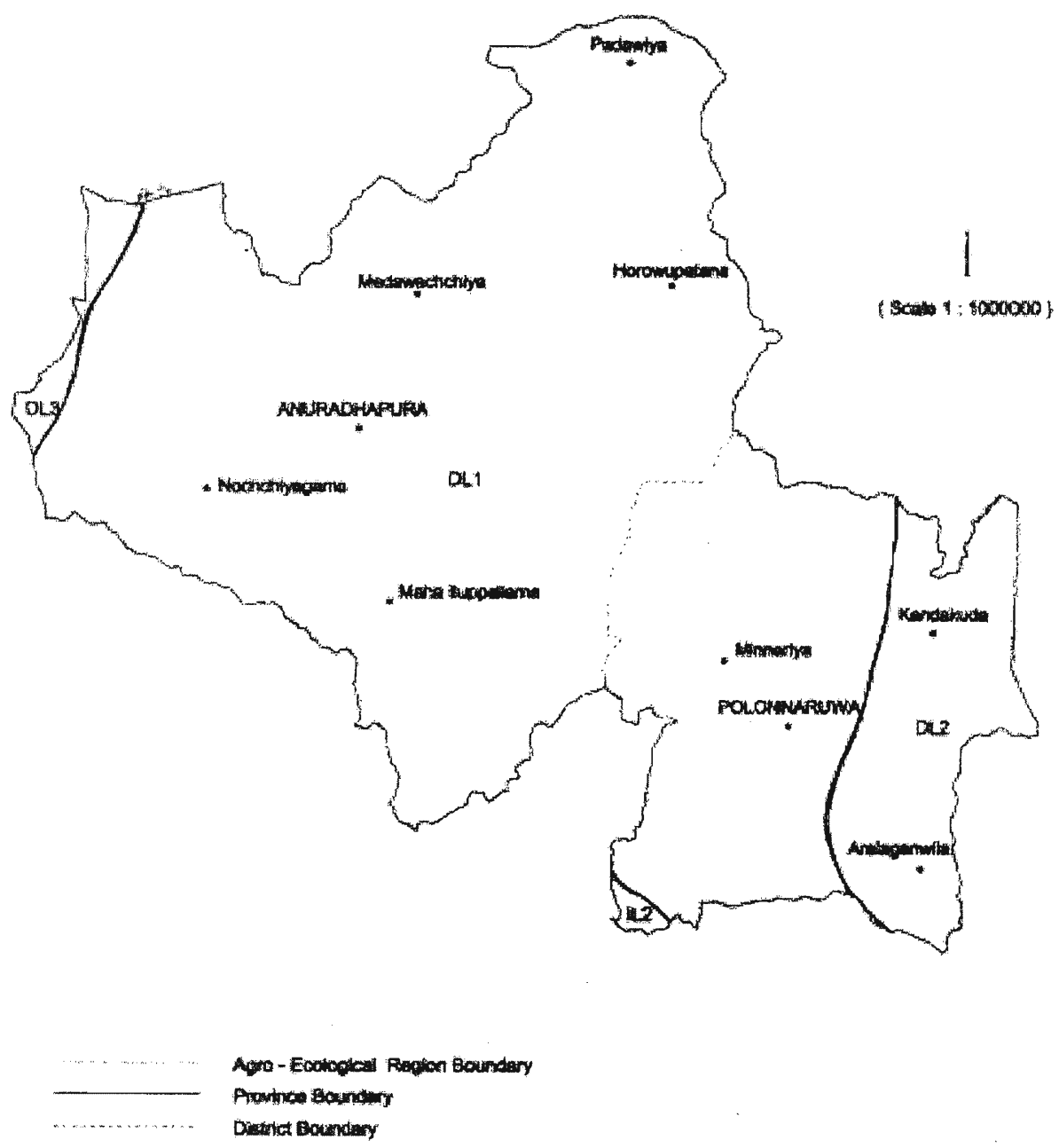

\section{Figure 1: Agro-ecological regions in the North Central Province}

The climate, in particular, rainfall of $\mathrm{DL}_{1}$ region of the NCP exhibits a definite rhythm, mainly attributed to the causes of the seasonal rainfall. During the period of October to November, this region along with the other parts of the country receives ample rains from the Second Inter-Monsoon (SIM) rains, which generally occur due to passage of an Inter Tropical Convergence Zone (ITCZ) over the country. The ITCZ, generally, enhances the regional convection and thus forms low level disturbances and depressions in the vicinity of Sri Lanka. Nevertheless, 
when the ITCZ is not active, the rainfall during this period is mainly governed by the convectional activity due to intense heating of land. By December, the NCP begins to receive the North East Monsoon (NEM) rains which would generally extend up to mid January of the following year. Together with the rains of October and November, these NEM rains make up the distinct cultivation season, the Maha season. When Maha rains retreat, a dry weather usually prevails during late January to early March. By mid March, the $\mathrm{DL}_{1}$ region generally experiences convectional rains in the form of high intensity rains, possibly with thunder. These rains could occur up to early May and it represents the other distinct cultivation season, the Yala season. When the South West Monsoon (SWM) blows over the Wet Zone during the period of mid May to September, the $\mathrm{DL}_{1}$ region of the NCP experiences a characteristic dry season due to Föhn like conditions of the SWM air flow. The rainfall during this period will mainly be in the form of occasional convectional type showers due to intense heating of land during daytime. Due to differences in terrain and albedo across the province, these rains possess a very high spatial variability. However, development of weather systems in the vicinity of Sri Lanka when the "monsoon break" conditions appear during SWM period cause considerable rainfall in the NCP

Apart from the conventional dry period, which comes during mid May to September, dry spells and droughts could occur during any part of the year due to significant negative departures of seasonal rainfall. Meanwhile, excess rainfall during major cultivation seasons does occur inflicting heavy crop losses with subsequent serious social impacts on the society. All these anomalies, either positive or negative, are said to be more frequent and intense during recent times than ever before. These rainfall departures are commonly attributed to shifts in frequency and strength of $E l$ Niño/La Niña events in the central and eastern Pacific ocean. Some recent studies have emphasized the teleconnection between rainfall in Sri Lanka and occurrence of El Niño/La Niña events. ${ }^{1-6}$ However, comprehensive climatological analyses have not been undertaken for the NCP within the context of agricultural production. Hence, this study was undertaken to investigate the influence of $E l N i \tilde{n} o / L a$ Niña episodes on the seasonal rainfall climatology of the $\mathrm{DL}_{1}$ agro-ecological region of North Central Province of Sri Lanka.

\section{METHODS AND MATERIALS}

The rainfall data used in this study consists of daily rainfall data from two representative locations of the NCP, namely, Maha-Illuppallama and Minneriya for the period 1906 to 2000. Even though daily rainfall data from some other stations in the $\mathrm{DL}_{1}$ region are also available, limited length of those data prevented using them in the study. These daily data were grouped into four different rainfall seasons for use in the study. These seasons are First Inter-Monsoon convectional rainy season (FIM; March-April), South West Monsoon rainy season (SWM; May-September), Second Inter-Monsoon rainy season (SIM; October-November) and North East 
Monsoon rainy season (NEM; December-February). The status of each year in terms of El Niño, La Niña or Neutral, during the period from 1906 to 2000 was identified using published information and was verified against the Southern Oscillation Index (SOI) data taken from the Bureau of Meteorology, Australia. ${ }^{7}$

In this study, a year has been defined from March of one year to February of the subsequent year. This period includes the peak months of El Niño and $L a$ Niña events during October to December. From the original data set of 1906 to 2000, three data sub-sets were extracted for El Niño, La Niña, and Neutral years. For each type of year, cumulative seasonal rainfall and number of rainy days in each season were determined. A day was considered as a rainy day when the cumulative daily rainfall catch equals or exceeds $0.3 \mathrm{~mm}$. The differences of mean seasonal rainfall in El Niño-Neutral and La Niña-Neutral were tested with student t-test. Further, the Chi-square test was adopted to test the differences between number of rainy days in each season among different types of years.

\section{RESULTS AND DISCUSSION}

Table 1 shows the mean seasonal rainfall during El Niño and Neutral years at Maha-Illuppallama and Minneriya. At both locations, SIM rains were significantly higher during El Niño years than Neutral years. A similar trend was observed in number of rainy days (Table 2). However, the magnitude of the increase in mean SIM rainfall was higher at Minneriya where the reported increase was 37\% compared to $20 \%$ increase at Maha-Illuppallama. These results are in agreement with the findings of previous studies. ${ }^{6}$ The significantly enhanced rainfall regime during SIM could probably be attributed to the exceptionally high Sea Surface Temperature (SST) during El Niño years in some regions of the Indian Ocean and its associated convective activity. ${ }^{4}$

Table 1: Seasonal rainfall of $\mathrm{DL}_{1}$ agro-ecological region in the NCP during El Niño and Neutral years

\begin{tabular}{lcccc}
\hline \multirow{2}{*}{ Season } & \multicolumn{4}{c}{ Seasonal rainfall - $\mathrm{mm}$} \\
\cline { 2 - 5 } & \multicolumn{2}{c}{ Maha-Illuppallama } & \multicolumn{2}{c}{ Minneriya } \\
& El Niño & Neutral & El Niño & Neutral \\
\hline \multirow{2}{*}{ FIM } & 306 & 354 & 192 & 213 \\
SWM & 190 & 186 & 264 & 241 \\
SIM & $600^{*}$ & 499 & $666^{*}$ & 486 \\
NEM & 392 & 375 & 693 & 602 \\
\hline
\end{tabular}

"Significantly different at $5 \%$ probability level 
Table 2: Occurrence of rainy days during $E l$ Niño and Neutral years at $\mathrm{DL}_{1}$ agro-ecological region of the NCP

\begin{tabular}{lcccc}
\hline \multirow{2}{*}{ Season } & \multicolumn{4}{c}{ Number of rainy days } \\
\cline { 2 - 5 } & Maha-Illuppallama & \multicolumn{2}{c}{ Minneriya } \\
& 21 & Neutral & El Niño & Neutral \\
FIM & 17 & 21 & 14 & 17 \\
SWM & $35^{*}$ & 17 & 10 & 10 \\
SIM & 27 & 30 & $32^{*}$ & 27 \\
NEM & 25 & 31 & 30 \\
\hline
\end{tabular}

* Significantly different at $5 \%$ probability level

During El Niño years, NEM rains were also increased by $5 \%$ and $15 \%$ at Maha-Illuppallama and Minneriya, respectively. But, these positive anomalies were not significant (Table 1). Moreover, there was no appreciable change in the number of rainy days of NEM during El Niño years over the Neutral years (Table 2). Thus, it is clear that even though El Niño episodes are at their peak during NEM season, enhanced rainfall regime during previous two months (SIM) begins to decline during NEM. It should be noted that out of three months of the NEM, only December and first week of January give substantial rainfall to this region. Dry weather usually prevails during the rest of the NEM season. Hence, positive rainfall anomalies that may arise due to $E l$ Niño type weather conditions during first half of the NEM may not be sufficient to make a significant signatory on mean seasonal rainfall of three month period i.e. December through February. Nevertheless, when the magnitude of the increase in NEM rains is considered, the influence of El Niño events is more pronounced at Minneriya (15\% increase) where the NEM is effective for two months compared to Maha-Illuppallama ( $5 \%$ increase) where only December and a few days of early January receive NEM rains.

There were no discernible trends in FIM and SWM rains at both locations in response to the occurrence of El Niño events (Table 1). Table 2 reveals that mean number of rainy days in these two seasons has also no apparent trend. The lack of any significant association between occurrence of $E l$ Niño events and FIM rains could be attributed to the fact that El Niño events are generally at their early stages of development in the east and central Pacific oceans when the FIM rains are effective over the Dry Zone. Hence, it may not be strong enough to influence the general circulation of the atmosphere and/or SSTs in the vicinity of Sri Lanka to cause a tangible impact on FIM rains. Even though SWM brings ample rain to the western part of the island, it blows over the NCP as a föhn like dry desiccating wind. Thus, any rainfall that is received in the NCP during SWM period is mainly due to convection on a local scale. Hence, even if teleconnections between El Niño 
events and SWM do exist, it may not be noticed in the rainfall of NCP during SWM period.

Table 3: Seasonal rainfall of $\mathrm{DL}_{1}$ agro-ecological region in the NCP during La Niña and Neutral years

\begin{tabular}{lcccc}
\hline \multirow{2}{*}{ Season } & \multicolumn{4}{c}{ Seasonal rainfall - $\mathrm{mm}$} \\
\cline { 2 - 5 } & \multicolumn{2}{c}{ Maha-Illuppallama } & \multicolumn{2}{c}{ Minneriya } \\
& La Niña & Neutral & La Niña & Neutral \\
\hline \multirow{2}{*}{ FIM } & 324 & 354 & 206 & 213 \\
SWM & $281^{*}$ & 186 & 258 & 241 \\
SIM & 401 & 499 & $383^{*}$ & 486 \\
NEM & 353 & 375 & 606 & 602 \\
\hline
\end{tabular}

* Significantly different at $5 \%$ probability level

Table 4: Occurrence of rainy days during La Niña and Neutral years at $\mathrm{DL}_{1}$ agro-ecological region of the NCP

\begin{tabular}{lcccc}
\hline \multirow{2}{*}{ Season } & \multicolumn{4}{c}{ Number of rainy days } \\
\cline { 2 - 5 } & \multicolumn{2}{c}{ Maha-Illuppallama } & \multicolumn{2}{c}{ Minneriya } \\
& La Niña & Neutral & La Niña & Neutral \\
\hline \multirow{2}{*}{ FIM } & 20 & 21 & 15 & 17 \\
SWM & $23^{*}$ & 17 & 13 & 10 \\
SIM & 28 & 30 & 23 & 27 \\
NEM & 25 & 25 & 27 & 30 \\
\hline
\end{tabular}

* Significantly different at 5\% probability level

An apparent decreasing trend was evident between occurrence of La Niña events and seasonal rainfall during FIM, SIM and NEM at both locations compared to Neutral years. Out of those, the decreasing trend of SIM rains in La Niña years at Minneriya was significant. In contrast, the teleconnection between seasonal rainfall of SWM and La Niña events was positive at both locations. Nevertheless, it was significant only at Maha-Illuppallama (Table 3). A similar trend was also observed in the mean number of rainy days (Table 4). In general, the atmospheric circulation during $L a$ Niña years is an intensification of the normal situation. Thus, it would probably intensify the SWM rains in the southwestern part, the socalled Wet Zone of Sri Lanka. ${ }^{2}$ Under such situation, the warmth of the NCP is likely to increase due to katabatic nature of this wind and as such it may enhance 
the local convection. During SWM period, the major rainfall producing mechanism in the NCP is local level convection. Therefore, during La Niña years an enhanced rainfall regime of SWM could be anticipated.

\section{CONCLUSION}

This study clearly demonstrates that there is an influence of El Niño and La Niña episodes on the seasonal rainfall regime of $\mathrm{DL}_{1}$ region. In general, both rainfall and the number of rainy days in SIM season showed a statistically significant increase with respect to the situation in the Neutral years. Even though it was not significant, there was an apparent increasing trend of NEM rains during $E l$ Niño years. Thus, El Niño years are likely to produce above normal or at least near normal rains during the Maha season in the NCP. Hence, appearance and progression of El Niño type circulation in the Pacific ocean could be safely used as a long-range forecasting tool for rainfall of the Maha season in the NCP. Although there were obvious differences of seasonal time series of FIM, SIM and NEM between La Niña and Neutral years, statistically significant relationships could not be established. Meanwhile, the teleconnection between seasonal rainfall of SWM and La Niña events was positive at both locations. Accumulation of rainfall time series over the period of seasons covering several overlapping months would have obscured some of the significant anomalies that exist during the El Niño and La Niña years. Hence, the temporal sub divisions of seasonal rainfall into smaller time intervals would be recommended in future studies.

\section{Acknowledgement}

Authors wish to thank the Department of Meteorology for providing rainfall data for this study through the Center for Climate Change Studies.

\section{References}

1 Kane R.P. (1998). ENSO relationship to the rainfall in Sri Lanka. International Journal of Climatology 18: 859-871.

2 Punyawardena B.V.R. \& Cherry N.J. (1999). Assessment of the predictability of seasonal rainfall in Ratnapura using the southern oscillation and its two extremes. Journal of the National Science Council of Sri Lanka 27(3):187195.

3 Rasmusson E.M. \& Carpenter T.H.(1983). The relationship between eastern equatorial Pacific sea surface temperature and rainfall over India and Sri Lanka. Monthly Weather Review 111:517-528. 
4 Sumathipala W.L. (1999). Characteristics of the ENSO in the Indian Ocean. Proceedings of the $15^{\text {th }}$ technical session, March 1999. pp 74-80. Institute of Physics.

5 Sumathipala W.L \& Punyadeva. (1998). Variation of rainfall of Sri Lanka in relation to El Nino. Proceedings of the $14^{\text {th }}$ technical session, March 1998.pp: 12-19. Institute of Physics.

6 Suppiah R. (1997). Extremes of southern oscillation phenomenon and the rainfall of Sri Lanka. International Journal of Climatology 17: 87-101.

7. Bureau of Meteorology (1997). SOI Archives 1876 to present. http:// www.bom.gov.au/climate/current/html. 